\title{
Caecal perforation with faecal peritonitis - unusual presentation of Bochdalek hernia in an adult: a case report and review of literature Ameet Kumar*1, Vikas Maheshwari' ${ }^{1}$, TS Ramakrishnan ${ }^{1}$ and Samaresh Sahu ${ }^{2}$
}

\author{
Address: ${ }^{1}$ Department of Surgery, Air Force Hospital,, Nathu Singh Road, Kanpur Cantt Uttar Pradesh, India and ${ }^{2}$ Department of Radiology, Air \\ Force Hospital,, Nathu Singh Road, Kanpur Cantt, Uttar Pradesh, India \\ Email: Ameet Kumar* - mythurs@hotmail.com; Vikas Maheshwari - maheshwari_kavi@rediffmail.com; TS Ramakrishnan -dr.tsrk@gmail.com; \\ Samaresh Sahu - sahu.samaresh@gmail.com \\ * Corresponding author
}

Published: 6 May 2009

World Journal of Emergency Surgery 2009, 4:16 doi:10.1 186/1749-7922-4-16

This article is available from: http://www.wjes.org/content/4/1/16

(C) 2009 Kumar et al; licensee BioMed Central Ltd.

This is an Open Access article distributed under the terms of the Creative Commons Attribution License (http://creativecommons.org/licenses/by/2.0), which permits unrestricted use, distribution, and reproduction in any medium, provided the original work is properly cited.
Received: 4 February 2009

Accepted: 6 May 2009

\begin{abstract}
The improper fusion of the postero-lateral foramen of the diaphragm was first described by Bochdalek in 1848. The incidence of congenital diaphragmatic hernia varies from I:2000 to I:5000 live births and Bochdalek hernias $(\mathrm{BH})$ account for 75 to $85 \%$ of these. Although it is a well-known entity in neonates, it is occasionally discovered incidentally in adult patients. Until now, a total of around 100 cases of occult asymptomatic Bochdalek hernia have been reported. The symptomatic cases are encountered more rarely. Colon necrosis among the symptomatic cases was reported in some reports. We discuss the present case since we believe it to be, to the best of our knowledge, the first case of a Bochdalek hernia in an adult presenting with caecal perforation and faecal peritonitis and review the published literature about this rare condition.
\end{abstract}

\section{Introduction}

A diaphragmatic hernia may be congenital or secondary to a traumatic rupture of the diaphragm. The incidence of congenital diaphragmatic hernia $(\mathrm{CDH})$ varies from 1:2000 to 1:5000 live births [1]. Bochdalek hernias (BH) and Morgagni hernias (MH) account for 75 to $85 \%$ and 1 to $6 \%$ among causes of $\mathrm{CDH}$, respectively. Most CDHs are diagnosed antenatally or in the neonatal period and only $5 \%$ of $\mathrm{CDH}$ present after neonatal period. Approximately, over 100 cases of occult Bochdalek hernias in asymptomatic adults have been reported in the literature $[2,3]$. According to a review report presented in 1995 , there were only five previous cases in which the colon was found in the thorax [4]. A medline search has revealed only a few cases of colonic necrosis in symptomatic cases wherein primary colo-colonic anastomosis was employed [3]. Another case presenting with perforation of the transverse colon was managed with Video assisted thoracoscopic surgery (VATS) and laparotomy [5]. We herein report the present case since we believe it to be the first adult Bochdalek hernia presenting with perforation of the caecum and faecal peritonitis secondary to a closed loop obstruction and review the published literature.

\section{Case Report}

A 46-year-old male patient presented to our emergency department with a history of generalized abdominal pain of 7 days' duration. The pain had become more localized to the right lower abdomen for the last 2 days. There was a history of constipation lasting for 3 days. There was no vomiting and he did not have any chest or abdominal complaints in the past. There were no known co-morbidities. There was no history of recent trauma or surgery. On physical examination, he was febrile (101 Fahrenheit) and had tachycardia. Abdomen was distended and the 
liver dullness was obliterated. There was generalized abdominal tenderness in addition to rebound tenderness in the right iliac fossa. The bowel sounds were absent. The haemogram showed leucocytosis (11000/Cu mm). Chest X-ray showed free air under the diaphragm (Fig 1) and abdominal X-rays showed a markedly dilated transverse colon. A preoperative diagnosis of hollow viscus perforation with peritonitis was made and the patient was taken up for emergency laparotomy. On laparotomy, there was caecal perforation with faecal peritonitis (Fig 2). There was marked dilatation of the caecum, ascending colon and transverse colon up to the level of splenic flexure of the colon. The descending colon was collapsed and there was no mass or band causing the obstruction. The dilated transverse colon was followed and it became evident that it was entering the pleural cavity through a postero-lateral defect in the diaphragm (Fig 3). A dilated loop of transverse colon was found in the chest cavity with obstruction at the level of the defect. This loop along with its mesentery was viable and brought down into the abdominal cavity by enlarging the defect in diaphragm (Fig 4). The defect was primarily repaired in one layer with interrupted sutures of No-1 prolene and a left intercostal tube drain (ICD) with negative pressure was placed. The caecal perforation was managed by intracaecal placement of a Foley urethral catheter of 20 French to establish a tube caecostomy. In the postoperative period, ICD was removed on the 5 th postoperative day. The patient developed mild infection at the laparotomy wound which was treated by conservative regimen. The caecostomy tube was removed after 3 weeks and the patient was subsequently discharged from the hospital.

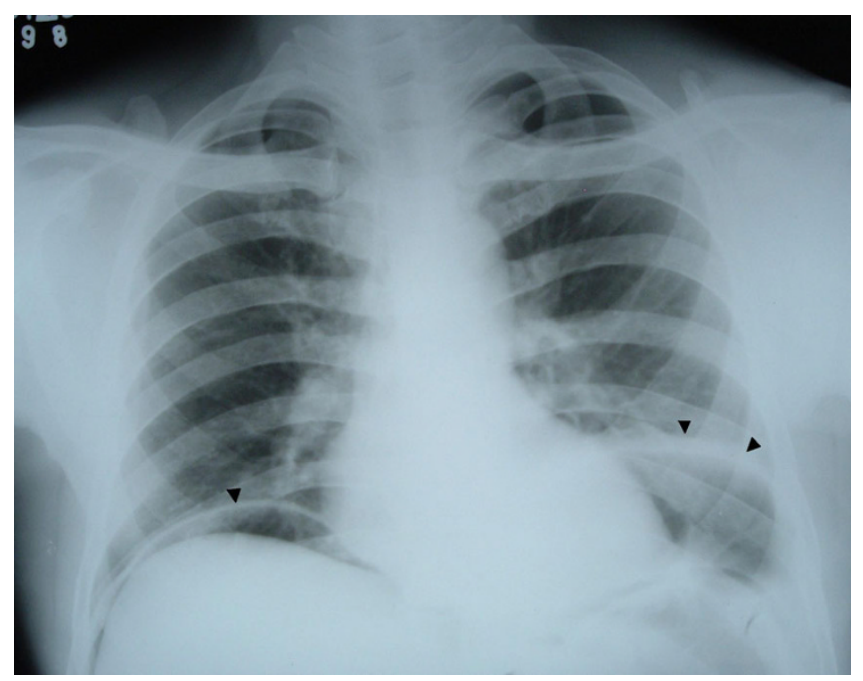

Figure I

Chest X-ray showing free air under diaphragm (single arrow head) along with the Bochdalek hernia on the right side (double arrow head).

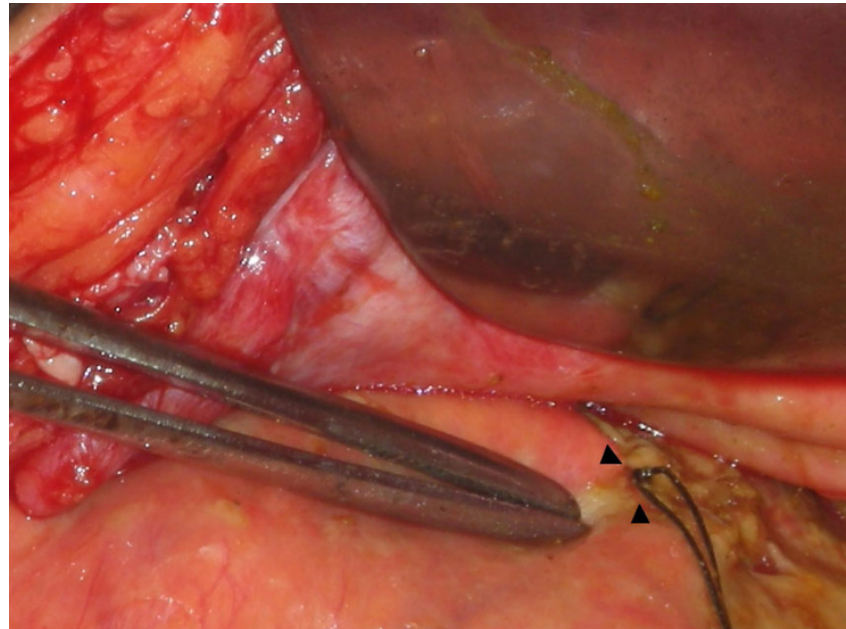

Figure 2

Intraoperative picture showing markedly dilated caecum with perforation temporarily controlled by silk sutures.

\section{Discussion}

Although the initial records of diaphragmatic hernia date back as far as the 1690s [6], the improper fusion of the postero-lateral foramina of the diaphragm was first described by Bochdalek in $1848[7,8]$. The true incidence of asymptomatic Bochdalek hernia remains unknown and ranges from $1 / 7,000$ to $6 \%[7,9]$. There is also reported predominance on the right side in asymptomatic cases [2]. Undiagnosed patients may never be identified as having Bochdalek hernia [2]. The left-sided presentation

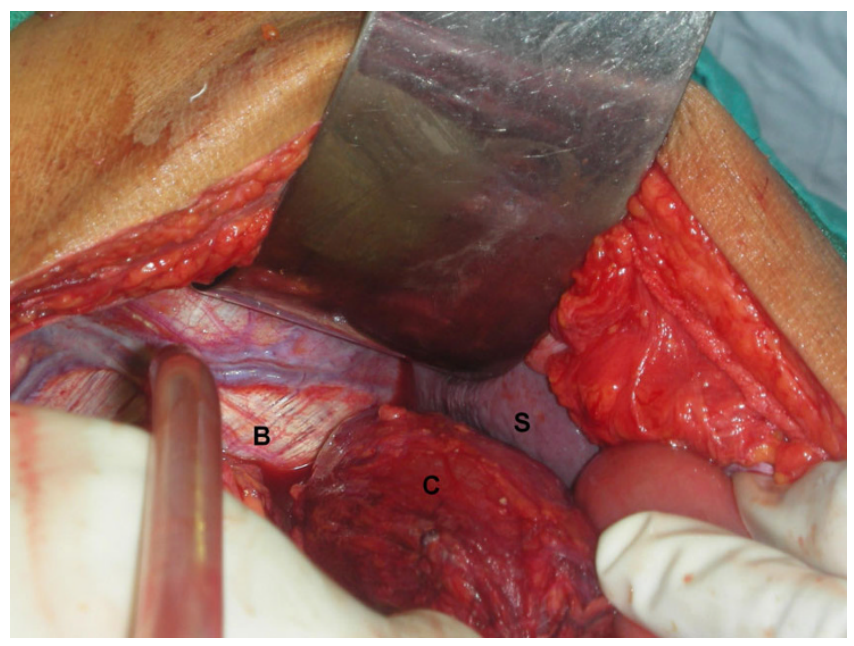

Figure 3

Intraoperative picture showing transverse colon entering the posterolateral defect in the left diaphragm, B: Bochdalek hernia, S: Spleen, C: Transverse Colon. 


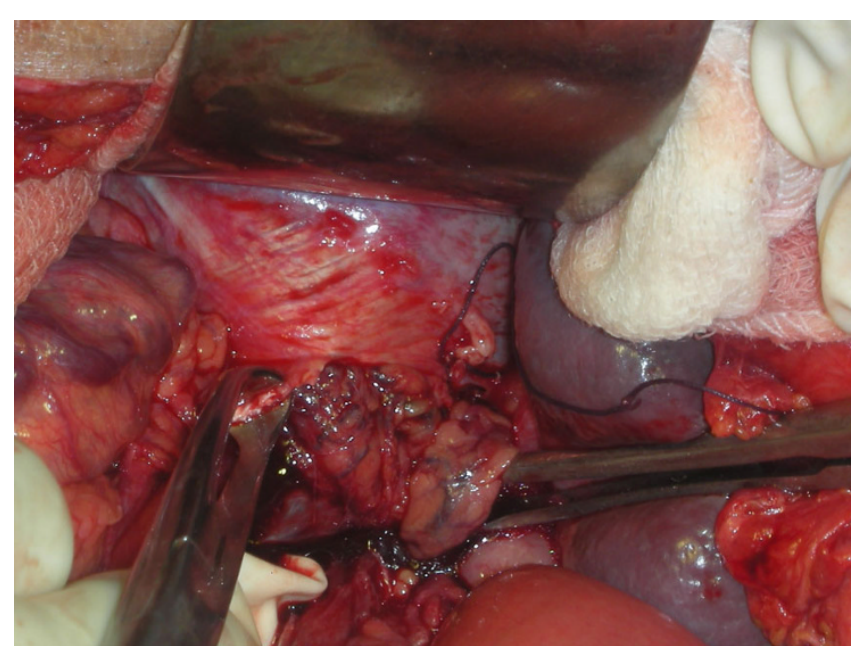

Figure 4

Intraoperative picture of the defect having been enlarged to reduce the hernia.

in our patient is in accord with the majority of cases reported in the literature. During the formation of the diaphragm, the pleural and coelomic cavities remain in continuity by means of the pleuroperitoneal canal. The posterolateral communication is the last to be closed by the developing diaphragm. Failure of the diaphragmatic development leaves a posterolateral defect symptomatic mostly on the left side. The defective closure of the pleuroperitoneal canal leads to three types of congenital hernias: the posterolateral (Bochdalek hernia), anterolateral and pars sternalis. The posterolateral subgroup accounts for $81 \%$ of these congenital diaphragmatic hernias [10]. Most of the Bochdalek hernias are diagnosed in children who present with pulmonary symptoms $[6,7,11]$. Since Bochdalek hernia in an adult is an asymptomatic condition, it is usually an incidental finding which makes its incidence difficult to be estimated. These can sometimes present with vague chest and gastrointestinal symptoms $[6,11]$. The predominance of the left side in symptomatic cases both in neonates and adults may be due to narrowing of the right pleuroperitoneal canal by the caudate lobe of the liver [12]. Another reason may be that the right pleuroperitoneal canal closes earlier. According to a recent report in 2002, there are only seven symptomatic cases involving the right hemidiaphragm in the literature [13]. The hernial size varies and the content of the hernial sac may differ from each other in every age group. Hernias on the left side may contain intestinal loops, spleen, liver, pancreas, kidney or fat. Colon in a Bochdalek hernia is a rare condition and usually found in the left-sided hernias as was also the case in our patient $[7,14]$. A medline search for cases of colon in a $\mathrm{BH}$ revealed about 32 cases (Table 1) [15-39]. A coexisting hernial sac has also been reported in $10-38 \%$ of the cases according to large series [7]. Some authors believe that long-term survival may be due to the persistence of a pleuroperitoneal sac (hernial sac) and that the rupture of the sac in adult life may trigger the characteristic symptoms [40]. There was no hernial sac in our patient. Drugs such as thalidomide or antiepileptics administered during pregnancy i.e. before the closure of the pleuroperitoneal canal before 9th to 10th weeks' gestation along with the genetic predisposition have been incriminated as the etiological factors. A congenital diaphragmatic hernia can be accompanied by other congenital anomalies in 25-57\% and by chromosomal disorders in $10-20 \%$ of cases [10]. Our patient did not have any obvious congenital anomaly. Bochdalek hernias may show up on chest X-rays as air and fluid-filled viscera in the hemithorax, as in our case. Associated mechanical obstruction may be obvious on plain X-ray imaging. Contrast-enhanced computed tomography (CT) has been an increasingly important investigation method in assessment of acute presentation which was not used in our case. The rare finding of a dilated bowel above the hemidiaphragm makes the diagnosis obvious. Other investigations including upper gastrointestinal contrast studies can exclude malrotation [41]. Gastrointestinal contrast studies could not be done since our case was an emergency situation. A delayed or missed diagnosis of diaphragmatic hernia can lead to significant morbidity and mortality [42]. The diagnosis of Bochdalek hernia in adults is not easy, and on a couple of occasions has been misdiagnosed as pneumothorax and managed initially by a chest tube drainage resulting in feculent discharge from the chest and delayed discovery of hernia [5,43]. Management of a Bochdalek hernia includes reducing the abdominal contents and repairing the defect through a laparotomy or thoracotomy. The best approach for management of hernias occurring on the left side is controversial. Those who advocate a thoracotomy claim about the improved ability to separate adhesions between thoracic viscera and the hernial sac [42]. Those in favour of a laparotomy believe that the abdominal approach is superior to thoracotomy for the recognition and management of a possible concomitant malrotation and for dealing with visceral complications such as obstruction or strangulation [44]. Oliveira et al. favour a combined approach (laparotomy plus thoracotomy) for the right-sided cases to facilitate the replacement of the herniated viscera and to close the diaphragmatic defect to overcome the mass effect of the liver [45]. Our patient underwent an emergency laparotomy because of the presence of hollow viscus perforation with peritonitis. In the postoperative period, complications like abdominal compartment syndrome have been reported in literature following repair of an adult Bochdalek hernia [46,47]. The overall mortality in $\mathrm{BH}$ is around $12 \%$. It is higher following emergency laparotomies (32\%) than after elective surgery (3\%) [48]. More recently, successful laparoscopic [49] and thoracoscopic 
Table I: Summary of cases of Bochdalek hernia involving colon published in literature

\begin{tabular}{|c|c|c|c|c|c|c|c|}
\hline Reference No & No of cases & Age & Sex & Presentation & Side & Operative Findings & Operative Procedure \\
\hline 15 & 1 & $76 y$ & M & $\begin{array}{l}\text { Dyspnoea/intestinal } \\
\text { obstruction }\end{array}$ & Right & $\begin{array}{l}\text { Strangulation of a portion of } \\
\text { transverse colon }\end{array}$ & $\begin{array}{l}\text { Resection-anastomosis; } \\
\text { primary repair }\end{array}$ \\
\hline 16 & 1 & $45 y$ & $\mathrm{~F}$ & Pain abdomen & Right & Volvulus of colon & $\begin{array}{l}\text { Right hemicolectomy; Primary } \\
\text { repair }\end{array}$ \\
\hline 17 & 1 & 3 days & M & Respiratory distress & Right & $\begin{array}{l}\text { Herniated small bowel, colon } \\
\text { and liver }\end{array}$ & Thoracoscopic patch repair \\
\hline 18 & I & Young & $M$ & Abdominal pain & Left & Incarcerated colon & Primary repair \\
\hline 19 & I & $42 y$ & $\mathrm{~F}$ & $\begin{array}{l}\text { Abdominal pain, post } \\
\text { prandial vomiting }\end{array}$ & Left & Sealed perforation of colon & $\begin{array}{l}\text { Combined thoracoscopic and } \\
\text { laparoscopic repair }\end{array}$ \\
\hline 20 & 1 & $16 y$ & M & Vomiting & Left & $\begin{array}{l}\text { Stomach, spleen, part of the } \\
\text { small intestine and colon in } \\
\text { left hemithorax. }\end{array}$ & Primary repair \\
\hline 21 & I & $6 \mathrm{~m}$ & M & Bilious vomiting & Left & $\begin{array}{l}\text { Herniated stomach, small } \\
\text { intestine, part of colon and } \\
\text { spleen }\end{array}$ & Laparoscopic repair \\
\hline 22 & I & 35 y & $\mathrm{F}$ & Intestinal obstruction & Right & $\begin{array}{l}\text { Herniated colon with } \\
\text { concurrent appendicitis }\end{array}$ & $\begin{array}{l}\text { Appendicectomy, primary } \\
\text { repair }\end{array}$ \\
\hline 23 & 1 & $2 y$ & M & $\begin{array}{l}\text { Recurrent pulmonary } \\
\text { infections }\end{array}$ & Right & $\begin{array}{l}\text { Dilated colon loops and right } \\
\text { kidney }\end{array}$ & Thoracotomy, primary repair \\
\hline 3 & 1 & $21 y$ & M & -- & Left & Colonic necrosis & $\begin{array}{l}\text { Resection anastomosis; } \\
\text { primary repair }\end{array}$ \\
\hline 5 & 1 & $46 y$ & $\mathrm{~F}$ & $\begin{array}{l}\text { Abdominal pain, } \\
\text { vomiting }\end{array}$ & Left & $\begin{array}{l}\text { Colonic perforation } \\
\text { (following chest tube } \\
\text { insertion) }\end{array}$ & $\begin{array}{l}\text { VATS combined with } \\
\text { laparotomy; resection } \\
\text { anastomosis with primary } \\
\text { repair }\end{array}$ \\
\hline 24 & I & $25 y$ & $\mathrm{~F}$ & -- & Left & $\begin{array}{l}\text { Herniated stomach, } \\
\text { transverse colon, spleen }\end{array}$ & Laparoscopic repair \\
\hline 25 & 1 & 41 y & $\mathrm{F}$ & $\begin{array}{l}\text { Abdominal pain, } \\
\text { vomiting }\end{array}$ & Left & $\begin{array}{l}\text { Herniated stomach, } \\
\text { transverse colon, spleen }\end{array}$ & Primary repair \\
\hline 26 & I & -- & -- & -- & Right & -- & -- \\
\hline 13 & 1 & $63 y$ & $\mathrm{~F}$ & $\begin{array}{l}\text { Abdominal pain, } \\
\text { dyspnoea }\end{array}$ & Right & Strangulated colon; kidney & $\begin{array}{l}\text { Resection anastomosis; } \\
\text { primary repair }\end{array}$ \\
\hline 27 & I & Adult & $\mathrm{F}$ & Pain abdomen & Left & Gastric volvulus; colon & Laparoscopic repair \\
\hline 28 & I & $9 y$ & $\mathrm{~F}$ & $\begin{array}{l}\text { Cough, vomiting, } \\
\text { anorexia }\end{array}$ & Right & Colon & Primary repair \\
\hline 29 & 2 & Infants & & Cough, vomiting & Right/Left & $\begin{array}{l}\text { Colon, small intestine and } \\
\text { stomach }\end{array}$ & Primary repair \\
\hline 30 & 1 & $49 y$ & $\mathrm{~F}$ & Chronic cough & Left & Small intestine, colon & $\begin{array}{l}\text { Hand assisted thoracoscopic } \\
\text { prolene mesh repair }\end{array}$ \\
\hline 31 & I & $38 y$ & $\mathrm{~F}$ & $\begin{array}{l}\text { Abdominal pain, } \\
\text { nausea }\end{array}$ & Left & Incarcerated transverse colon & Thoracotomy, primary repair \\
\hline \multirow[t]{2}{*}{32} & 2 & $9 y$ & $\mathrm{~F}$ & $\begin{array}{l}\text { Abdominal pain, } \\
\text { vomiting }\end{array}$ & Left & $\begin{array}{l}\text { Small intestine, colon and } \\
\text { stomach }\end{array}$ & Thoracotomy, primary repair \\
\hline & & 35 y & M & Dyspnoea & Left & $\begin{array}{l}\text { Small intestine, colon and } \\
\text { stomach }\end{array}$ & Thoracotomy, primary repair \\
\hline 33 & I & $53 y$ & M & Intestinal obstruction & -- & Obstructed colon & Primary repair \\
\hline 4 & I & I y & $\mathrm{F}$ & $\begin{array}{l}\text { Fever, left pleural } \\
\text { effusion, vomiting }\end{array}$ & Left & Colonic hernia & Primary repair \\
\hline 34 & I & $17 y$ & $\mathrm{~F}$ & -- & Left & Stomach, colon; hemorrhage & Primary repair \\
\hline 43 & 1 & $70 y$ & M & Dyspnoea & Left & $\begin{array}{l}\text { Perforated colon following } \\
\text { thoracic drain insertion }\end{array}$ & $\begin{array}{l}\text { Combined thoracotomy and } \\
\text { laparotomy; primary repair and } \\
\text { colostomy }\end{array}$ \\
\hline 35 & 1 & $70 y$ & $\mathrm{~F}$ & $\begin{array}{l}\text { Abdominal pain, right } \\
\text { chest pain }\end{array}$ & Right & $\begin{array}{l}\text { Colopleural fistula due to } \\
\text { Strangulated colon }\end{array}$ & Colostomy; primary repair \\
\hline 36 & 1 & $40 y$ & M & $\begin{array}{l}\text { Mild nonspecific left } \\
\text { chest pain }\end{array}$ & Left & Patient declined surgery & \\
\hline 37 & I & $5 y$ & $M$ & Asymptomatic & Right & Stomach, colon & Primary repair \\
\hline 38 & I & -- & $\mathrm{F}$ & $\begin{array}{l}\text { Abdominal pain, } \\
\text { vomiting }\end{array}$ & -- & Incarcerated colon & Primary repair \\
\hline 39 & 1 & $5 y$ & $M$ & $\begin{array}{l}\text { Dyspnoea, abdominal } \\
\text { pain }\end{array}$ & Left & Herniated colon & Primary repair \\
\hline
\end{tabular}

Total number of cases: 32 
repairs of the left sided Bochdalek hernia have both been described $[5,50]$. Some authors have also described hand assisted thoracoscopic repair of Bochdalek hernia [51]. Minimal invasive surgery is reported to be ideal for Morgagni defects, with a success rate of $90.9 \%$ with only one recurrence in a series, whereas it cannot be recommended in newborns with Bochdalek hernia because of high failure rates. It can be and should be considered for adults since the success rate increases with increasing age [52]. As our patient was operated on in a surgical emergency setup caused by intestinal obstruction and hollow viscus perforation, a laparoscopic intervention was not possible.

\section{Conclusion}

Bochdalek hernia is an uncommon variant of diaphragmatic hernias in adults and symptomatic cases are even rarer. Often, these cases present with chronic chest or abdominal symptoms and rarely present as an emergency like the present case with hollow viscus perforation and peritonitis. We want to emphasize the point that, though rare, diaphragmatic hernias should be kept in mind while considering all possibilities of the differential diagnosis of acute surgical abdomen in an adult, especially when a conventional plain X-ray reveals some abnormal findings.

\section{Competing interests}

The authors declare that they have no competing interests.

\section{Authors' contributions}

AK carried out the surgery, researched the article and drafted the manuscript.

VM assisted in the surgery, researched the article and drafted the manuscript.

TSR assisted in the surgery, edited and revised the manuscript.

SS carried interpreted the imaging studies, edited and revised the manuscript.

All authors read and approved the final manuscript.

\section{Consent}

Written informed consent was obtained from the patient for publication of this case report and accompanying images. A copy of the written consent is available with the corresponding author for review by Editor-in Chief.

\section{References}

I. Adelman S, Benson CD: Bochdalek hernias in infant: Factors determining mortality. J Pediatr Surg. I976, I I (4):569-573.

2. Mullins ME, Stein J, Saini SS, Mueller PR: Prevalence of incidental Bochdalek's hernia in a large adult population. AJR Am J Roentgenol 2001, I 77:363-366.

3. Kocakusak A, Arikan S, Senturk O, Yucel AF: Bochdalek's hernia in an adult with colon necrosis. Hernia 2005, 9:284-287.
4. Betremieux P, Dabadie A, Chapuis M, Pladys P, Treguier C, Fremond $B$, Lefrancois $C$ : Late presenting Bochdalek hernia containing colon: misdiagnosis risk. Eur J Pediatr Surg 1995, 5: I I3-I I5.

5. Chai Y, Zhang G, Shen G: Adult Bochdalek hernia complicated with a perforated colon. J Thorac Cardiovasc Surg 2005, 130:1729-1730.

6. Fine R, Borrero $\mathrm{E}$, Stone A: Bochdalek hernia in adulthood. $N Y$ State J Med 1987, 87:516-518.

7. Salacin S, Alper B, Cekin N, Gulmen MK: Bochdalek hernia in adulthood: a review and autopsy case report. J Forensic Sci. 1994, 39(4): III2-III6.

8. Haller JA: Professor Bochdalek and his hernia: then and now. Prog Paediatr Surg 1986, 20:252-255.

9. Houben JJ, De Laet MH, Godart S, Bouckaert J, Govaerts M, Bouton JM, Collier F, Dereere R, Derom F, Vansande S: Bochdalek's congenital diaphragmatic hernia: a clinical review of 114 cases. Acta Chir Belg 1984, 84:7-I2.

10. Detti L, Mari G, Ferguson JE: Color Doppler ultrasonography of the superior mesenteric artery for prenatal ultrasonographic diagnosis of a left-sided congenital diaphragmatic hernia. J Ultrasound Med 200I, 20:689-692.

II. Hines GL, Romero C: Congenital diaphragmatic hernia in the adult. Int Surg 1983, 68:349-35I.

12. Wells LJ: Development of the human diaphragm and pleural sacs. Carnegie Institution of Washington Publication 603, Contrib Embryol 1954, 35:107-134.

13. Kanazawa A, Yoshioka Y, Inoi O, Murase J, Kinoshita H: Acute respiratory failure caused by an incarcerated right-sided adult Bochdalek hernia: report of a case. Surg Today 2002, 32:8I2-8I5.

14. Losanoff JE, Sauter ER: Congenital posterolateral diaphragmatic hernia in an adult. Hernia 2004, 8:83-85.

15. Kavanagh DO, Ryan RS, Waldron R: Acute dyspnoea due to an incarcerated right-sided Bochdalek's hernia. Acta Chir Belg 2008, 108(5):604-6.

16. Lucisano AM, Pafundi DP, Calabria R, Orsini V, Sacco R: Congenital diaphragmatic hernia in an adult: case report of acute abdomen. Chir ltal 2008, 60(4):583-6.

17. Shah SR, Gittes GK, Barsness KA, Kane TD: Thoracoscopic patch repair of a right-sided congenital diaphragmatic hernia in a neonate. Surg Endosc 2009, 23(1):215.

18. Mohammadhosseini B, Shirani S: Incarcerated Bochdalek hernia in an adult. J Coll Physicians Surg Pak 2008, 18(4):239-4I.

19. Esmer D, Alvarez-Tostado J, Alfaro A, Carmona R, Salas M: Thoracoscopic and laparoscopic repair of complicated Bochdalek hernia in adult. Hernia 2008, I 2(3):307-9.

20. Nicho Salvador H, Acuna Fernández L, Amado Ramírez J, Nicho Gómez A: Bochdalek's hernia in a mentally retarded adolescent. Rev Gastroenterol Peru 2007, 27(2): 194-8.

21. Kohno M, Ikawa H, Okamoto S, Fukumoto H, Masuyama H, Konuma $\mathrm{K}$ : Laparoscopic repair of late-presenting Bochdalek hernia in 2 infants. Surg Laparosc Endosc Percutan Tech 2007, 17(4):3 I 7-2I.

22. Rout S, Foo FJ, Hayden JD, Guthrie A, Smith AM: Right-sided Bochdalek hernia obstructing in an adult: case report and review of the literature. Hernia 2007, I I(4):359-62.

23. Karaoglanoglu N, Turkyilmaz A, Eroglu A, Alici HA: Right-sided Bochdalek hernia with intrathoracic kidney. Pediatr Surg Int 2006, 22( ( 2): | 029-3I.

24. Senkyrík M, Husova L, Lata J, Horalek F, Neubauer J: Uncommon case of a giant diaphragmatic hernia in a pregnant patient. Vnitr Lek 200I, 47(3): 185-9.

25. Hamoudi D, Bouderka MA, Benissa N, Harti A: Diaphragmatic rupture during labor. Int J Obstet Anesth 2004, I 3(4):284-6.

26. Rimpilainen J, Kariniemi J, Wiik H, Biancari F, Juvonen T: Post-traumatic herniation of the liver, gallbladder, right colon, ileum, and right ovary through a Bochdalek hernia. Eur J Surg 2002, 168(II):646-7.

27. Harinath G, Senapati PS, Pollitt MJ, Ammori BJ: Laparoscopic reduction of an acute gastric volvulus and repair of a hernia of Bochdalek. Surg Laparosc Endosc Percutan Tech 2002, I2(3): 180-3.

28. Bjelica Rodic B, Ljustina Pribic R, Petrovic S, Bogdanovic D: Congenital postero-lateral right diaphragmatic hernia-case report. Med Pregl 2000, 53(II-12):613-6. 
29. Tsuji K, Hori K, Suehisa H, Mitani H, Saito M, Ando T: A surgical case of adult Bochdalek hernia assisted by thoracoscopic surgery. Kyobu Geka 2000, 53(6):519-2I.

30. Ozturk H, Karnak I, Sakarya MT, Cetinkurşun S: Late presentation of Bochdalek hernia: clinical and radiological aspects. Pediatr Pulmonol 200I, 3 I (4):306-I0.

3I. liai T, Ohmori K, Ohtaki M, Mishina T, Saitoh H, Ishihara R, Suzuki N Adult Bochdalek hernia after playing at a tug of war. Kyobu Geka 1997, 50( I I):968-70.

32. Ohura H, Kondo T, Iwabuchi S, Matsumura $Y$, Saito R, Okada $Y$, Okaniwa G, Fujimura S: Two cases of the congenital posterolateral diaphragmatic hernia were reported. Kyobu Geka 1996, 49(5):420-3

33. Platz A, Saurenmann $P$, Decurtins $M$ : Colon ileus in Bochdalek hernia in adulthood. Chirurg 1996, 67(5):560-2.

34. Miller BJ, Martin IJ: Bochdalek hernia with hemorrhage in an adult. Can J Surg 1993, 36(5):476-8.

35. Sinha M, Gibbons P, Kennedy SC, Matthews HR: Colopleural fistula due to strangulated Bochdalek hernia in an adult. Thorax I989, 44(9):762-3.

36. Ramani A, Kumar V, Kundaje GN: Bochdalek diaphragmatic hernia. J Assoc Physicians India 1988, 36(5):349.

37. Pousse $H$, Hamza $H$, Bechraoui T, Sfar MT, Daoud $N$ : Unusual aspects of the late manifestations of diaphragmatic hernia. Radiol 1987, 68(2): 105-7.

38. Gimovsky ML, Schifrin BS: Incarcerated foramen of Bochdalek hernia during pregnancy. A case report. J Reprod Med 1983, 28(2): I56-8.

39. Day B: Late appearance of Bochdalek hernia. $\mathrm{Br}$ Med J 1972 , I(5803):786.

40. Osebold WR, Soper RT: Congenital posterolateral diaphragmatic hernia past infancy. Am J Surg 1976, I 3 I:748-754.

41. Wilbur AC, Gorodetsky A, Hibblen JF: Imaging Findings of adult Bochdalek hernias. Clin Imaging I 994, I 8:224-229.

42. Sugg WL, Roper CL, Carlsson E: Incarcerated Bochdalek hernias in the adult. Ann Surg 1964, 160:847-85I.

43. Kashima $\mathrm{T}$, Inoue $\mathrm{K}$, Kume $\mathrm{M}$, Takaba $\mathrm{T}$, Makita $\mathrm{T}$ : A case of intrathoracic colon perforation due to adult Bochdalek hernia. Kyobu Geka 1993, 46(9):819-22.

44. Fingerhut $A$, Baillet $P$, Oberlin $P$, Ronat $R$ : More on congenital diaphragmatic hernia in the adult [letter]. Int Surg 1984, 69: $182-183$

45. de Oliveira F, Oliveira FJ: Congenital posterolateral diaphragmatic hernia in the adult. Can J Surg 1984, 27:610-6II.

46. Panagiotis $H$, Panagiotis $D$, Nikolaos A, lon B: Abdominal com partment syndrome post-late Bochdalek hernia repair: $A$ case report. Cases Journal 2008, I:199.

47. Dalencourt G, Katlic M: Abdominal Compartment Syndrome after late repair of Bochdalek Hernia. Ann Thorac Surg 2006, 82:72I-2.

48. Fingerhut A, Pourcher J, Pelletier JM, Berteaux D, Bourdain JL, Nouailhat F: Two cases of postero-lateral diaphragmatic hernia (congenital Bochdalek hernia) revealed at adult age by severe complications. Operation and cure review of the literature. J Chir (Paris) 1978, I I 5: I35-143.

49. Wadhwa A, Surendra JBK, Sharma A, Khullar R, Soni V, Baijal M, Chowbey PK: Laparoscopic repair of diaphragmatic hernias: experience of six cases. Asian J Surg 2005, 28: I45-I50.

50. Yamaguchi M, Kuwano H, Hashizume M, Sugio K, Sugimachi K, Hyoudou $Y$ : Thoracoscopic treatment of Bochdalek hernia in the adult: report of a case. Ann Thorac Cardiovasc Surg 2002, 8:106-108.

51. Mousa A, Sanusi M, Lowery RC, Genovesi MH, Burack JH: Handassisted thoracoscopic repair of a Bochdalek hernia in an adult. J Laparoendosc Adv Surg Tech A 2006, I 6(I):54-8.

52. Arca MJ, Barnhart DC, Lelli JL Jr, Greenfeld J, Harmon CM, Hirschl RB, Teitelbaum DH: Early experience with minimally invasive repair of congenital diaphragmatic hernias: results and lessons learned. J Pediatr Surg 2003, 38: I563-8.
Publish with Bio Med Central and every scientist can read your work free of charge

"BioMed Central will be the most significant development for disseminating the results of biomedical research in our lifetime. "

Sir Paul Nurse, Cancer Research UK

Your research papers will be:

- available free of charge to the entire biomedical community

- peer reviewed and published immediately upon acceptance

- cited in PubMed and archived on PubMed Central

- yours - you keep the copyright

Submit your manuscript here:

http://www.biomedcentral.com/info/publishing_adv.asp
BioMedcentral 